\title{
Concepts in Turbocharging for Improved Efficiency and Emissions Reduction
}




\title{
Other SAE books of interest:
}

Automotive 2030-North America

By Bruce Morey

(Product Code: T-127)

Design of Racing and High-Performance Engines 2004-2013

By Douglas Fehan

(Product Code: PT-157)

Introduction to Internal Combustion Engines, 4th Edition

By Richard Stone

(Product Code: R-391)

\author{
For more information or to order a book, contact: \\ SAE INTERNATIONAL \\ 400 Commonwealth Drive \\ Warrendale, PA 15096 \\ Phone: +1.877 .606 .7323 (U.S. and Canada only) \\ or +1.724 .776 .4970 (outside U.S. and Canada) \\ Fax: +1.724.776.0790 \\ Email: CustomerService@sae.org \\ Website: books.sae.org
}




\section{Concepts in Turbocharging for Improved Efficiency and Emissions Reduction}

Edited by Mehrdad Zangeneh

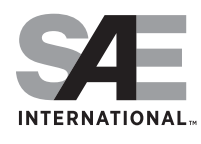


Copyright $\odot 2015$ SAE International. All rights reserved.

No part of this publication may be reproduced, stored in a retrieval system, distributed, or transmitted, in any form or by any means without the prior written permission of SAE International. For permission and licensing requests, contact SAE Permissions, 400 Commonwealth Drive, Warrendale, PA 15096-0001 USA; e-mail: copyright@sae.org; phone: +1-724-772-4028; fax: +1-724-772-9765.

\section{Library of Congress Catalog Number 2014947146 SAE Order Number PT-156 DOI 10.4271/PT-156}

Information contained in this work has been obtained by SAE International from sources believed to be reliable. However, neither SAE International nor its authors guarantee the accuracy or completeness of any information published herein and neither SAE International nor its authors shall be responsible for any errors, omissions, or damages arising out of use of this information. This work is published with the understanding that SAE International and its authors are supplying information, but are not attempting to render engineering or other professional services. If such services are required, the assistance of an appropriate professional should be sought.

ISBN-Print 978-0-7680-7976-0

ISBN-PDF 978-0-7680-8149-7

ISBN-epub 978-0-7680-8151-0

ISBN-prc 978-0-7680-8150-3

To purchase bulk quantities, please contact

SAE Customer Service

e-mail: CustomerService@sae.org

phone: +1.877.606.7323 (inside USA and Canada)

+1.724 .776 .4970 (outside USA)

fax: +1.724.776.0790

Visit the SAE Bookstore at 


\section{Table of Contents}

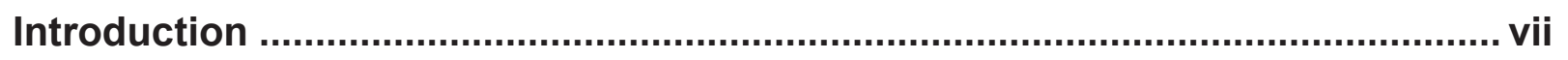

\section{Two-Stage Turbocharging}

Challenges for Increased Efficiency through Gasoline Engine

Downsizing-2009-01-1053 1

\section{Variable Geometry Compressors}

The Potential of Variable Compressor Geometry for Highly Boosted Gasoline

Engines-2011-01-0376 19

Turbocharging of Downsized Gasoline DI Engines with 2 and

3 Cylinders-2011-24-0138

Variable Geometry Diffuser of Turbocharger Compressor for Passenger

Vehicles-2003-01-0051

\section{Unconventional Compressor Configurations}

Parametric Studies of the Impact of Turbocharging on Gasoline Engine Downsizing-2009-01-1472

\section{Electrically Assisted Turbocharging}

Coordinated Electric Supercharging and Turbo-Generation for a Diesel Engine-2010-01-1228.

About the Editor 81 